\title{
VIROLOGICAL AND SEROLOGICAL DIAGNOSIS OF RABIES IN BATS FROM AN URBAN AREA IN THE BRAZILIAN AMAZON
}

\author{
Rubens Souza de OLIVEIRA(1,3), Lanna Jamile Corrêa da COSTA(1), Fernanda Atanaena Gonçalves de ANDRADE(2), Wilson UIEDA(3), \\ Luzia Fátima Alves MARTORELLI(4), Ana Paula de Arruda Geraldes KATAOKA(4), Elizabeth Salbé Travassos da ROSA(5), \\ Pedro Fernando da Costa VASCONCELOS(5), Armando de Souza PEREIRA(5), \\ Antônio Ismael Barros do CARMO(6) \& Marcus Emanuel Barroncas FERNANDES(1)
}

\begin{abstract}
SUMMARY
The outbreaks of rabies in humans transmitted by Desmodus rotundus in 2004 and 2005, in the northeast of the Brazilian State of Para, eastern Amazon basin, made this a priority area for studies on this zoonosis. Given this, the present study provides data on this phenomenon in an urban context, in order to assess the possible circulation of the classic rabies virus (RABV) among bat species in Capanema, a town in the Amazon basin. Bats were collected, in 2011, with mist nets during the wet and dry seasons. Samples of brain tissue and blood were collected for virological and serological survey, respectively. None of the 153 brain tissue samples analyzed tested positive for RABV infection, but 50.34\% (95\% CI: 45.67-55.01\%) of the serum samples analyzed were seropositive. Artibeus planirostris was the most common species, with a high percentage of seropositive individuals $(52.46 \%, 95 \%$ CI: 52.31-52.60\%). Statistically, equal proportions of seropositive results were obtained in the rainy and dry seasons $\left(\chi^{2}=0.057\right.$, d.f. $=1$, $p=0.88)$. Significantly higher proportions of males (55.96\%, 95\% CI: 48.96-62.96\%) and adults (52.37\%, 95\% CI: 47.35-57.39\%) were seropositive. While none of the brain tissue samples tested positive for infection, the high proportion of seropositive specimens indicates that RABV may be widespread in this urban area.
\end{abstract}

KEYWORDS: Bats; Rabies; Serology; Urban area.

\section{INTRODUCTION}

Rabies is an anthropozoonosis that affects the Central Nervous System (CNS), causing acute infectious encephalomyelitis and, in most cases, death. The virus that causes this disease belongs to the genus Lyssavirus, Rhabdoviridae family, Mononegavirales order ${ }^{18}$, which has a number of different variants that may be maintained in one or more species, acting as regional hosts ${ }^{33}$. In Latin America, domestic dogs have always been considered to be the primary reservoir of the classic rabies virus (RABV), but since 2004, the common vampire bat, Desmodus rotundus (E. Geoffroy 1810), has become the principal vector and reservoir of this zoonosis ${ }^{36}$. This shift in the epidemiological profile of the disease has been particularly relevant in northern Brazil, where outbreaks of human rabies in 2004 and 2005 were caused by hematophagous bats in rural areas of the states of Para and Maranhao ${ }^{5,31,37}$, reflecting the widespread deforestation and associated environmental impacts that affect this region.

In urban areas, the number of cases of human rabies caused by dogs declined considerably in the Americas, as a result of the Pan-American Health Organization initiatives ${ }^{25}$, meanwhile the number of cases caused by bats increased, because of the aforementioned rural cases ${ }^{37}$. However, a number of South American studies have confirmed cases of rabies, in both bats and humans, in urban environments in countries such as Chile ${ }^{23}$ and Colombia ${ }^{3}$, as well as Brazilian cities, including Rio de Janeiro ${ }^{7}$, Ubatuba in Sao Paulo ${ }^{12}$, and Campo Grande in Mato Grosso do Sul ${ }^{10}$.

The outbreaks of rabies in humans caused by $D$. rotundus that occurred throughout much of the northeast of the state of Para, made this region an important area for the study of the virus and its vectors, although the researches were restricted to rural areas ${ }^{9}$. Given this, our study presents the first virological and serological diagnosis of RABV in bats, in an urban zone in the Brazilian Amazon region. The main aim of this study is to better understand the epidemiology of the zoonosis in this environment through the identification of potential vector species that may contribute to the transfer of RABV between rural and urban environments.

\section{METHODS}

Ethical statement: The collection and transportation of bat specimens and biological samples (brain tissue and blood) for scientific

(1) Universidade Federal do Pará, Bragança, PA, Brasil.

(2) Instituto Federal de Educação, Ciências e Tecnologia, Tucuruí, PA, Brasil.

(3) Universidade Estadual Paulista, Botucatu, SP, Brasil.

(4) Centro de Controle de Zoonoses, São Paulo, SP, Brasil.

(5) Instituto Evandro Chagas, Belém, PA, Brasil.

(6) Secretaria de Estado de Saúde Pública, Capanema, PA, Brasil.

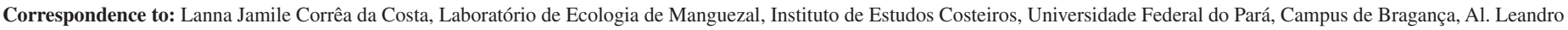
Ribeiro s/n, Aldeia, 68600-000 Bragança, Pará, Brasil. Phone/Fax: ++ 5591 34251209. E-mail: lannacorrea@yahoo.com.br 


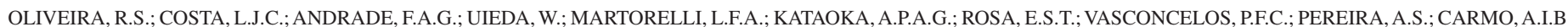
\& FERNANDES, M.E.B. - Virological and serological diagnosis of rabies in bats from an urban area in the Brazilian Amazon. Rev. Inst. Med. Trop. Sao Paulo, 57(6): 497-503, 2015.

purposes was authorized by the Federal Chico Mendes Institute for the Conservation of Biodiversity (ICMBio) through license number 23151-1, obtained on June 15, 2010.

Study site: The present study was conducted in the town of Capanema $\left(1.19^{\circ} \mathrm{S}, 47.18^{\circ} \mathrm{W}\right)$, which is located in the northeastern mesoregion of the Brazilian State of Para, in the eastern Amazon basin (Fig. 1). This municipality covers an area of $614,693 \mathrm{~km}^{2}$, at an altitude of 24 m a.s.1. ${ }^{19}$.

The region's climate is of Köppen's Am subtype, that is, equatorial hot and humid, with rainfall throughout the year, but distributed in a

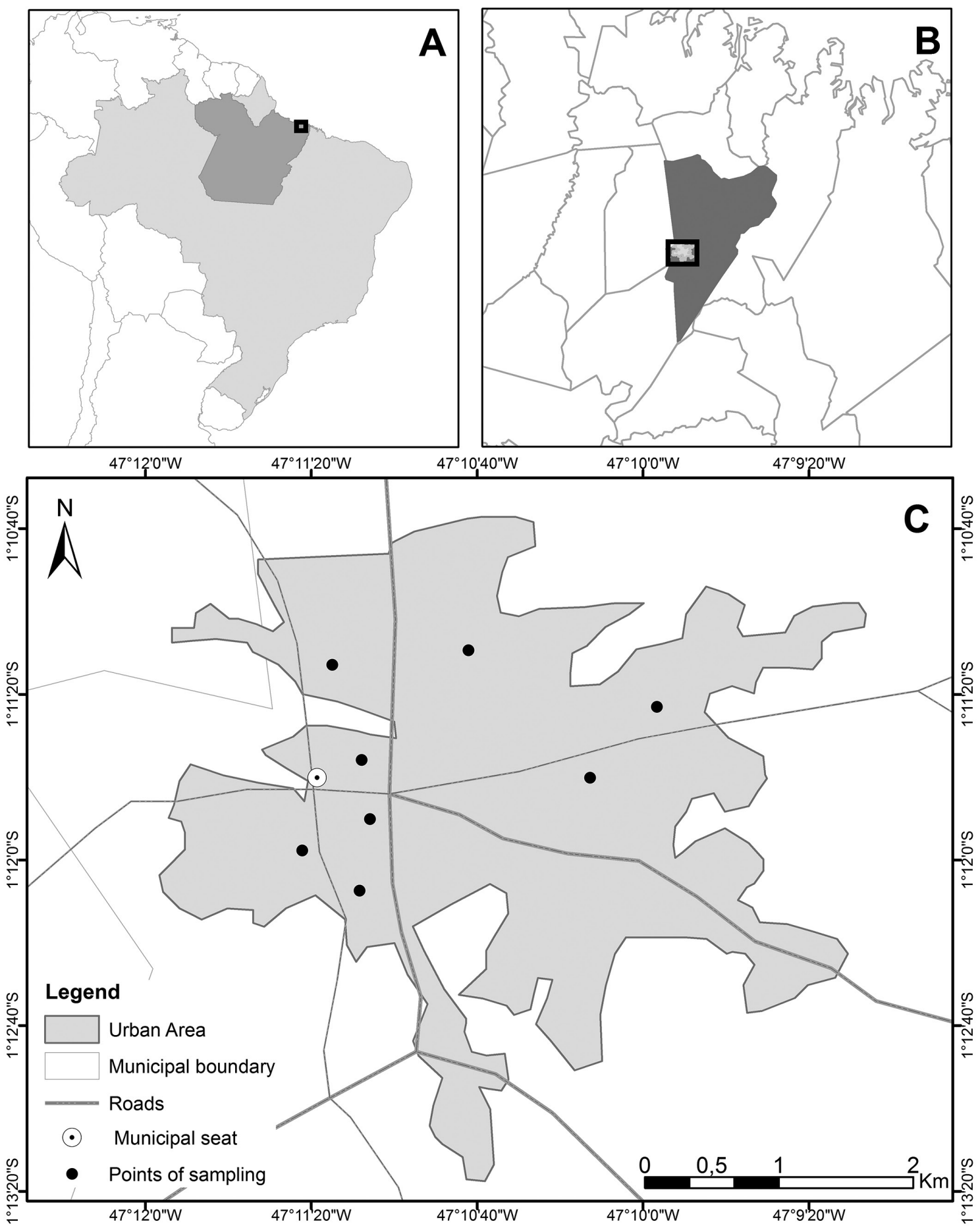

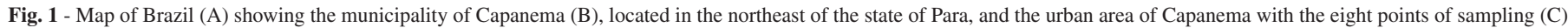




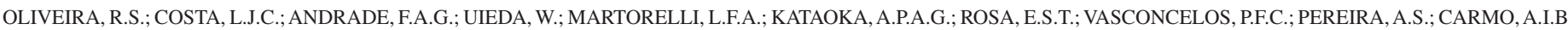
\& FERNANDES, M.E.B. - Virological and serological diagnosis of rabies in bats from an urban area in the Brazilian Amazon. Rev. Inst. Med. Trop. Sao Paulo, 57(6): 497-503, 2015.

wet season, between February and July, and a dry or less rainy season, between September and December. Annual precipitation is generally between $2,300 \mathrm{~mm}$ and $2,500 \mathrm{~mm}$, and mean annual temperatures range from $26.5^{\circ} \mathrm{C}$ to $31.5^{\circ} \mathrm{C}^{30}$.

Specimen collection: The specimens were collected in May/June and October/November, 2011, covering the dry and wet seasons, respectively. Ten mist nets ( $3 \mathrm{~m} \mathrm{x} 7 \mathrm{~m}$, with a $20 \mathrm{~mm}$ mesh) were employed at different sample points located next to wooded areas inside the town, likely to provide bats with resources (e.g., refuges, food). The nets were set $0.5 \mathrm{~m}$ above ground level between 6 p.m. and 1 a.m. during the waning and new moon. They were set up on two consecutive nights at each sampling point during each season, with a total of 16 nights of specimen collection in the dry season and 16 in the wet season. The captured bats were maintained in cotton bags prior to manipulation and the collection of blood samples, and were subsequently released at the capture site.

Identification of specimens and preparation of the voucher specimens: The bats captured in the mist nets were identified to species using a number of different dichotomous keys ${ }^{11,15,16,22}$ and the species were classified as in REIS et al. ${ }^{29}$. The age of the specimens was determined by the degree of epiphyseal discs fusion in the articulations of the hand, between the metacarpals and the phalanges ${ }^{1}$.

The specimens that had to be sacrificed for extraction of the brain tissue samples were labeled, fixed in $10 \%$ formalin and then conserved in $70 \%$ ethanol for subsequent taxonomic analysis. These specimens constitute the reference collection for the present study, and were deposited in the Braganca Zoological Collection at the Braganca campus of the Federal University of Para.

Collection and processing of serum samples: Blood samples of 0.2-0.3 mL were collected through cardiac puncture (in the case of the voucher specimens) using a $1 \mathrm{~mL}$ insulin syringe. In all other specimens, the blood samples were extracted from the propatagial vein, which was perforated with a hypodermic needle for the collection of drops of blood in a hematocrit tube ${ }^{4}$.

These samples were initially preserved at a temperature of $15^{\circ} \mathrm{C}$ for transportation to the laboratory, where they were centrifuged at 4,000 rpm for five minutes. The serum was removed and poured into sterilized microtubes and identified with individual codes prior to being stored at temperatures of $2-8{ }^{\circ} \mathrm{C}$ for subsequent transportation to the Laboratory for Zoonoses and Vector-transmitted Diseases of the Zoonosis Control Center (CCZ-SP) in Sao Paulo, Brazil. The samples were tested in this laboratory for the presence of neutralizing antibodies for RABV, using the Rapid Fluorescent Focus Inhibition Test (RFFIT), with a cutoff point of $0.5 \mathrm{IU} / \mathrm{mL}^{38}$.

Collection and processing of brain tissue samples: Prior to fixing the specimens in $10 \%$ formalin, samples of brain tissue were collected in the laboratory under aseptic conditions, using $170 \mathrm{~mm}$ polypropylene Pasteur-type pipettes with $3 \mathrm{~mm}$-diameter tips and a capacity of $3 \mathrm{~mL}$, which were introduced into the cranial cavity through the foramen magnum to retrieve the material by suction ${ }^{14}$. This method enables the brain tissue to be removed without damaging the cranium, which is an essential diagnostic criterion for the identification of some chiropteran species and storage in scientific collection.
The samples of brain tissue were conserved at $-70{ }^{\circ} \mathrm{C}$, and then sent to the Rabies Research and Diagnosis Laboratory of the Arbovirology and Hemorrhagic Fevers Sector at the Evandro Chagas Institute in Belem, Para, Brazil, where the samples were tested for rabies antigen using Direct Immunofluorescence (DIF) and Intracerebral Inoculation in Mice (IIM), following the recommendations of the World Health Organization ${ }^{24}$.

Data analysis: A Chi-square $\left(\chi^{2}\right)$ test was used to evaluate deviations in the proportion of seropositive specimens by age, sex or season. A multiple logistic regression was used to evaluate the probability of obtaining a seropositive specimen, according to its sex, age and the climatic season during which it was captured. The analyses were run in BioEstat 5.02.

\section{RESULTS}

A total of 441 bat specimens were captured, representing 10 different species (none of which were hematophagous), with RABV-neutralizing antibodies being detected in nine of these species (Table 1). The diagnosis of the serum samples nevertheless indicated that just over half $(50.34 \%$, $95 \%$ CI: $45.67-55.01 \%$ ) of the specimens captured were seropositive for the disease, with statistically equal portions of seropositive specimens being captured $\left(\chi^{2}=0.05\right.$, d.f. $=1, p=0.88$ ) (Table 1$)$. A total of 153 samples of brain tissue were analyzed from the 441 bats tested serologically, although none of these samples tested positive for RABV. This is despite the fact that more than half the specimens $(53.59 \%, 95 \%$ CI: 45.69-61.49\%) were seropositive (Table 1).

The most common species collected during the study was Artibeus planirostris (Table 1), with almost four fifths of all the specimens captured ( $\mathrm{n}=345,78.2 \%$ of the total). While a slightly higher proportion $(52.46 \%, 95 \%$ CI: $52.31-52.60 \%)$ of these specimens were seropositive in comparison with the overall mean $(50.34 \%)$; once again, there was no significant difference in the proportions of seropositive individuals $\left(\chi^{2}=0.838\right.$, d.f. $\left.=1, p=0.38\right)$. The second most common species, Carollia perspicillata, was represented by a much smaller proportion of the specimens collected $(\mathrm{n}=38,8.6 \%)$, with a much lower proportion (32.21\%, 95\% CI: $30.88-33.12 \%)$ of seropositive individuals. By contrast, Phyllostomus discolor, which represented less than 5\% $(n=22)$ of the specimens captured, had the highest proportion of seropositive individuals (63.64\%, 95\% CI: $54.09-71.91 \%)$. The next most common species was Glossophaga soricina, with 16 specimens captured, exactly half of which were seropositive. However, the main bat species to carry and transmit $\mathrm{RABV}, D$. rotundus, was not captured in the sampling plots of the city of Capanema.

Statistically equal proportions of seropositive individuals were recorded in the two seasons, with only a slightly higher proportion $(50.92 \%, 95 \% \mathrm{CI}: 44.28-57.56 \%)$ being recorded during the dry season $\left(\chi^{2}=0.057\right.$, d.f. $\left.=1, p=0.88\right)$ (Table 2$)$. A significantly higher proportion of males were seropositive (55.96\%, 95\% CI: 48.96-62.96\%), in comparison with the females $(45.97 \%, 95 \%$ CI: $39.77-52.17 \%)$ $\left(\chi^{2}=4.334\right.$, d.f. $\left.=1, p=0.04\right)$, and a significantly higher proportion of adults $(52.37 \%, 95 \%$ CI: $47.35-57.39 \%)$ were seropositive in comparison with the juveniles $(37.70 \%, 95 \%$ CI: $25.54-49.86 \%)\left(\chi^{2}=4.521\right.$, d.f. $=1$, $p=0.04$ ) (Table 2).

Significant differences were found in the distribution of seropositive 
OLIVEIRA, R.S.; COSTA, L.J.C.; ANDRADE, F.A.G.; UIEDA, W.; MARTORELLI, L.F.A.; KATAOKA, A.P.A.G.; ROSA, E.S.T.; VASCONCELOS, P.F.C.; PEREIRA, A.S.; CARMO, A.I.B. \& FERNANDES, M.E.B. - Virological and serological diagnosis of rabies in bats from an urban area in the Brazilian Amazon. Rev. Inst. Med. Trop. Sao Paulo, 57(6): 497-503, 2015.

Table 1

Number of seropositive bats analyzed for RABV antibodies (serum) in the urban zone of Capanema, Para (Brazil)

\begin{tabular}{|c|c|c|c|c|c|c|}
\hline \multirow[b]{2}{*}{ Taxon } & \multicolumn{3}{|r|}{ Serum } & \multicolumn{3}{|c|}{ Partial Serum 1} \\
\hline & $\mathbf{n}$ & n+ & $\%(\mathbf{C I})$ & $\mathbf{n}$ & n+ & $\%(\mathbf{C I})$ \\
\hline \multicolumn{7}{|l|}{ Family Emballorunidae } \\
\hline Rhynchonycteris naso (Wied-Neuwied, 1820) & 1 & 0 & 0 & 1 & 0 & 0 \\
\hline \multicolumn{7}{|l|}{ Family Phyllostomidae } \\
\hline \multicolumn{7}{|l|}{ Subfamily Glossophaginae } \\
\hline Glossophaga soricina (Pallas, 1766) & 16 & 8 & $50.00(25.50-74.50)$ & 5 & 2 & $40.00(02.94-82.94)$ \\
\hline \multicolumn{7}{|l|}{ Subfamily Phyllostominae } \\
\hline Lophostoma brasiliense Peters, 1866 & 2 & 1 & 50.00 (iss) & 2 & 1 & 50.00 (iss) \\
\hline Phyllostomus discolor Wagner, 1843 & 22 & 14 & $63.64(54.09-71.91)$ & 6 & 5 & 83.33 (iss) \\
\hline \multicolumn{7}{|l|}{ Subfamily Carolliinae } \\
\hline Carollia perspicillata (Linnaeus, 1758) & 38 & 13 & $32.21(30.88-33.12)$ & 12 & 6 & $50.00(21.71-78.29)$ \\
\hline \multicolumn{7}{|l|}{ Subfamily Stenodermatinae } \\
\hline Dermanura cinerea (Gervais, 1856) & 1 & 1 & 100 (iss) & 1 & 0 & 0 \\
\hline Artibeus planirostris Spix, 1823 & 345 & 181 & $52.46(52.31-52.60)$ & 118 & 65 & $55.08(46.10-64.05)$ \\
\hline Sturnira lilium (E. Geoffroy, 1810) & 5 & 2 & $40.00(02.94-82.94)$ & 2 & 0 & 0 \\
\hline Uroderma bilobatum Peters, 1866 & 2 & 1 & 50.00 (iss) & 2 & 1 & 50.00 (iss) \\
\hline \multicolumn{7}{|l|}{ Family Molossidae } \\
\hline Molossus molossus (Pallas, 1766) & 9 & 1 & $11.11(09.33-31.55)$ & 4 & 2 & $50.00(1.00-99.00)$ \\
\hline Total & 441 & 222 & $50.34(45.67-55.01)$ & 153 & 82 & $53.59(45.69-61.49)$ \\
\hline
\end{tabular}

n: number of individuals analyzed; $n+$ : number of seropositive bats; CI: 95\% confidence intervals; iss: insufficient sample size; Partial Sample 1: Serum of bats analyzed also by brain tissue.

Table 2

Prevalence of antibodies for the RABV in the bat specimens captured in Capanema, Para (Brazil) by season, age, and sex

\begin{tabular}{|c|c|c|c|c|c|c|c|c|c|}
\hline & \multicolumn{3}{|c|}{ Dry season } & \multicolumn{3}{|c|}{ Rainy season } & \multicolumn{3}{|r|}{ Total } \\
\hline & $\mathbf{n}$ & $\mathbf{n}+$ & $\%(\mathrm{CI})$ & $\mathbf{n}$ & $\mathbf{n}+$ & $\%(\mathrm{CI})$ & $\mathbf{n}$ & n+ & $\%(\mathrm{CI})$ \\
\hline Females & 120 & 60 & $50.00(41.06-58.94)$ & 128 & 54 & $42.19(33.63-50.75)$ & 248 & 114 & $45.97(39.77-52.17)$ \\
\hline Males & 98 & 51 & $52.04(42.15-61.93)$ & 95 & 57 & $60.00(50.15-69.85)$ & 193 & 108 & $55.96(48.96-62.96)$ \\
\hline Adults & 203 & 104 & $51.23(44.35-58.11)$ & 177 & 95 & $53.67(46.32-61.02)$ & 380 & 199 & $52.37(47.35-57.39)$ \\
\hline Juveniles & 15 & 7 & $46.67(21.42-71.92)$ & 46 & 16 & $34.78(21.02-48.54)$ & 61 & 23 & $37.70(25.54-49.86)$ \\
\hline Total & 218 & 111 & $50.92(44.28-57.56)$ & 223 & 111 & $49.78(43.22-56.34)$ & 441 & 222 & $50.34(45.67-55.01)$ \\
\hline
\end{tabular}

n: number of individuals analyzed; $n+:$ number of seropositive bats; CI: $95 \%$ confidence intervals.

specimens in relation to sex, age, and season $\left(\chi^{2}=9.294\right.$, d.f. $=3$, $p=0.02)$. In fact, the probability that an adult male was seropositive during the dry season $(67.79 \%)$ was close to double that $(41.06 \%)$ of a juvenile female during the wet season (Table 3). It is important to emphasize that, according to the multiple logistic regression, just the variable season showed no significant difference in relation to serology ( $\mathrm{z}=-0.2511, p=0.8017$ ) (Table 4 ). While there was no significant difference between seasons in the number of seropositive specimens, the highest probabilities (56.82-67.79\%) were recorded during the dry season (Table 3).

\section{DISCUSSION}

Just over half of the bats captured during the present study in the urban zone of Capanema were seropositive for RABV. This result was consistent with that of a previous study in a rural area, also on the east coast of Para, in the Brazilian Amazon region, where half of the bat specimens were also seropositive for this zoonosis ${ }^{9}$. Together with the findings of COSTA et al. ${ }^{9}$, from a rural area, the results of the present urban study indicate that the proportion of seropositive bats in the population may not vary significantly between urban and rural areas in the region of the eastern coast of Para. 


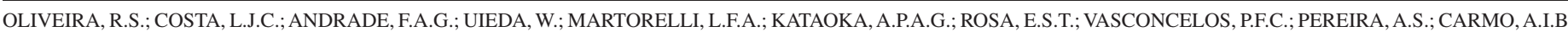
\& FERNANDES, M.E.B. - Virological and serological diagnosis of rabies in bats from an urban area in the Brazilian Amazon. Rev. Inst. Med. Trop. Sao Paulo, 57(6): 497-503, 2015.

Table 3

Probability values $(\mathrm{P}(\mathrm{Y}))$ estimated from the multiple logistic regression of the variables sex, age, and season

\begin{tabular}{lcc}
\hline Variables & Logit Pi & $\mathbf{P}(\mathbf{Y})$ \\
\hline males + adults + dry season & -0.7442 & 67.7914 \\
females + adults + dry season & -0.6949 & 66.71 \\
males + juveniles + dry season & -0.3239 & 58.0274 \\
females + juveniles + dry season & -0.2746 & 56.8222 \\
males + adults + rainy season & -0.1083 & 52.7049 \\
females + adults + rainy season & -0.059 & 51.4746 \\
males + juveniles + rainy season & 0.312 & 42.2627 \\
females + juveniles + rainy season & 0.3613 & 41.0645 \\
\hline
\end{tabular}

Table 4

Multiple logistic regression between the seroprevalence of antibodies for the RABV and Season, Sex and Age in the bats from in the urban zone of Capanema, Para (Brazil)

\begin{tabular}{lccc}
\hline Variables & Coefficients & $\boldsymbol{z}$ & $\boldsymbol{p}$ \\
\hline Season & -0.0493 & -0.2511 & 0.8017 \\
Sex & 0.4203 & 2.1608 & 0.0307 \\
Age & -0.6359 & -2.1871 & 0.0287 \\
\hline
\end{tabular}

The overall rate recorded in the urban and rural areas of the eastern coast of Para was relatively high, especially in comparison with results of studies conducted in other countries of Central and South America. In Colima, Mexico, for example, only $37 \%$ of non-hematophagous bats were seropositive ${ }^{34}$, while in Grenada and Trinidad, seropositive rates were $7.6 \%$ and $12.8 \%$, respectively, in hematophagous and non-hematophagous bats $^{39}$. In Peru, SALMON-MULANOVICH et al. ${ }^{35}$ recorded antibodies in $10.3 \%$ of hematophagous and non-hematophagous bats.

Regardless of the proportion of seropositive individuals found in the population, all studies throughout the world have found antibodies for rabies virus in non-hematophagous bats. In the present study, virtually all $(90 \%)$ of the species analyzed had seropositive individuals, indicating that most of the bat species found in this urban area may be exposed to RABV, even though some of these species are not included in the updated list of bats that have tested positive for rabies in Brazil ${ }^{39}$. Though rare, these species may contribute to the transmission of RABV in both rural and urban environments.

The presence of RABV in a number of different bat species inhabiting urban environments has been recorded in a number of previous studies $^{7,10,12,23}$. In the present study, A. planirostris was the most common species in terms of the number of specimens captured, and presented a high proportion $(52.46 \%)$ of seropositive individuals. Rabies positive specimens of this species have been captured in other urban areas ${ }^{10}$. In the present study, however, none of the specimens tested positive in the analysis of brain tissue, although the high percentage of seropositive individuals among the specimens captured clearly demands careful attention. This may be related primarily to the synanthropic habits of $A$. planirostris, which is common in urban environments, as are the other frugivorous and nectarivorous species analyzed in the present study ${ }^{6}$. Large numbers of seropositive A. planirostris were also captured by COSTA et al..$^{9}$ on the eastern coast of Para; thus, this species appears to be the most common incidental host of RABV in the eastern Brazilian Amazon at the present time.

The present study found no evidence of any seasonal tendency in the prevalence of RABV antibodies in the study populations. However, a number of studies have found seasonal patterns in the transmission of the virus, especially in relation to roost structure and the behavioral characteristics of the species that form maternity colonies ${ }^{13,17,41}$, although this question was not analyzed in the present study. COSTA et al. ${ }^{9}$ observed an increase in the prevalence of RABV antibodies during the wet season, which contradicts the results of the present study. This lack of any seasonal tendency may be related to the fact that, in the urban environment, bats could frequently share roosting sites with other species, independently of precipitation rates, maximizing contact between individuals throughout the year. Either way, it seems likely that a longerterm study will be necessary to confirm, or otherwise, any systematic seasonal pattern in the prevalence of RABV antibodies in the population.

The results of the present study indicated that males were significantly more likely to be seropositive than females, in contrast with other studies $^{26,27,41}$ that have recorded higher rates in females. This is almost certainly related to their more gregarious behavior, especially during the breeding season, when social grooming, nursing and olfactory or lingual contact with body fluids may increase considerably, facilitating the transmission of the virus. Even so, the prevalence of seropositive males found in the present study may be accounted for by the fact that they may be involved more frequently in intraspecific conflicts with subordinates or intruders, which can often involve biting ${ }^{8}$. When infected, dispersing males that attempt to form or take over new colonies may become potential and relevant transmitters of the rabies virus.

This may also have contributed to the high percentage of seropositive adults found in the present study. In fact, the regression analysis indicated a slightly higher probability that adult males will be seropositive (Table 3 ). In spite of this, some studies have recorded a greater prevalence of seropositive juveniles as a response to the transmission of the virus through bodily contact or the ingestion of infected maternal milk $\mathrm{k}^{40,41}$. It is likely that these seropositive adults had been in contact with infected juveniles in the roosts, especially following the breeding season, when non-reproductive males and females spend most of their time in the roost with the juvenile ${ }^{20}$. Lactating females, by contrast, must spend more time foraging due to their greater nutritional needs ${ }^{21}$. However, systematic evidence of sex-specific differences in susceptibility to RABV infection is lacking for most bat species.

None of the specimens we analyzed for infection, however, based on the analysis of brain tissues that tested positive none of the bats were actually infected with RABV. In spite of this, the number of seropositive specimens indicates that at least half of the bats of the different species captured had had some contact with RABV during the course of their lives, which presumably reflects the circulation of the virus within this urban area. The fact that none of the specimens captured was infected with RABV is consistent with the findings of RUPPRECHT ${ }^{32}$, who recorded a $1 \%$ infection rate in active bats, and concluded that infection alters 
OLIVEIRA, R.S.; COSTA, L.J.C.; ANDRADE, F.A.G.; UIEDA, W.; MARTORELLI, L.F.A.; KATAOKA, A.P.A.G.; ROSA, E.S.T.; VASCONCELOS, P.F.C.; PEREIRA, A.S.; CARMO, A.I.B. \& FERNANDES, M.E.B. - Virological and serological diagnosis of rabies in bats from an urban area in the Brazilian Amazon. Rev. Inst. Med. Trop. Sao Paulo, 57(6): 497-503, 2015.

the foraging behavior of these animals, making them less likely to fly at night, and thus less vulnerable to be captured in mist nets. Ultimately, our results may also indicate that, given the known cases of human and animal rabies transmitted by $D$. rotundus in the surrounding rural areas, the urban zone may provide a transmission route for the virus between different rural areas.

\section{RESUMO}

\section{Diagnóstico virológico e sorológico de raiva em morcegos de uma área urbana na Amazônia Brasileira}

Os surtos de raiva em humanos transmitida por Desmodus rotundus em 2004 e 2005 no nordeste do estado do Pará, Brasil, Amazônia Oriental, fizeram desta uma área prioritária para estudos sobre essa zoonose. Diante disso, o presente estudo fornece dados sobre esse fenômeno em contexto urbano, afim de avaliar uma possível circulação do vírus clássico da raiva (RABV) entre espécies de morcegos em Capanema, cidade localizada na bacia Amazônica. Os morcegos foram coletados em 2011, com auxílio de redes de espera durante as estações seca e chuvosa. Amostras de encéfalo e de sangue foram coletadas para o diagnóstico virológico e sorológico, respectivamente. Das 153 amostras de encéfalo analisadas, nenhuma encontrou-se positiva para infecção pelo RABV, porém, 50,34\% (95\% CI: 45,67-55,01) das amostras de soro analisadas estavam soropositivas. Artibeus planirostris foi a espécie mais comum, e seu percentual de indivíduos soropositivos foi bem elevado $(52.46 \%$, 95\% CI: 52,31-52,60). Porções estatisticamente iguais de soropositivos foram registrados nas estações $\left(\chi^{2}=0,057\right.$, d.f. $\left.=1, p=0,88\right)$. Uma porção significativamente elevada de machos $(55,96 \%, 95 \% \mathrm{CI}$ : $48,96 \%-62,96 \%)$, e adultos $(52,37 \%, 95 \%$ CI: 47,35\%-57,39\%) foram soropositivos. Apesar de nenhuma das amostras de encéfalo terem sido positivas para raiva, a alta proporção de espécimes soropositivos indica uma possível circulação do RABV nessa área urbana.

\section{ACKNOWLEDGMENTS}

We are grateful to Suzane Cerveira and Basílio Guerrero for their important help with the capture of bats, and Sanae N. Hayashi (UFRA) for producing the map of the study area.

\section{REFERENCES}

1. Anthony EL. Age determination in bats. In: Kunz TH, editor. Ecological and behavioral methods for the study of bats. Washington: Smithsonian Institution; 1988. p. 47-58.

2. Ayres M, Ayres MJ, Ayres DL, Santos AA. BIOESTAT: aplicações estatísticas nas áreas das ciências biomédicas. Belém: Instituto de Desenvolvimento Sustentável Mamirauá; 2007.

3. Badillo R, Mantilla JC, Pradilla C. Encefalitis rábica humana por mordedura de murciélago en área urbana de Colombia. Biomédica. 2009;29:191-203.

4. Baer GM, McLean RG. A new method of bleeding small and infants bats. J Mammalogy. 1972;53:231-2.

5. Barbosa TFS, Medeiros DBA, Travassos da Rosa ES, Casseb LM, Medeiros R, Pereira AS, et al. Molecular epidemiology of rabies virus isolated from different sources during a bat-transmitted human outbreak occurring in Augusto Corrêa municipality, Brazilian Amazon. Virology. 2008;370:228-36.
6. Bredt A, Uieda W, Pedro WA. Plantas e morcegos na recuperação de áreas degradadas e na paisagem urbana. Brasília: Rede de Sementes do Cerrado; 2012.

7. Cabral CC, Morais ACN, Dias AVAB, Araújo MG, Moreira WC, Mattos GL. Circulation of the rabies virus in non-hematophagous bats in the city of Rio de Janeiro, Brazil, during 2001-2010. Rev Soc Bras Med Trop. 2012;45:180-3.

8. Cortês VA, Souza LC, Uieda W, Figueiredo AC. Abrigos diurnos e infecção rábica em morcegos de Botucatu, São Paulo, Brasil. Vet Zootec. 1994;6:179-86.

9. Costa LJC, Andrade FAG, Uieda W, Martorelli LFA, Kataoka APAG, Fernandes MEB. Serological investigation of rabies virus neutralizing antibodies in bats captured in the eastern Brazilian Amazon. Trans R Soc Trop Med Hyg. 2013;107:684-9.

10. Deus GT, Becer M, Navarro IT. Diagnóstico da raiva em morcegos não hematófagos na cidade de Campo Grande, Mato Grosso do Sul, Centro Oeste do Brasil: descrição de casos. Semina Ciênc Agrárias. 2003;24:171-6.

11. Eisenberg JF, Redford KH. Mammals of the Neotropics. The Central Neotropics: Ecuador, Peru, Bolivia, Brazil. Chicago: University of Chicago Press; 1999. v. 3.

12. Ferraz C, Achkar SM, Kotait I. First report of rabies in vampire bat (Desmodus rotundus) in an urban area, Ubatuba, São Paulo State, Brazil. Rev Inst Med Trop Sao Paulo. 2007;49:389-90.

13. George DB, Webb CT, Farnsworth ML, O'Shea TJ, Bowen RA, Smith DL, et al. Host and viral ecology determine bat rabies seasonality and maintenance. Proc Natl Acad Sci USA. 2011;108:10208-13.

14. Gonçales JF, Carvalho C, Pedro WA, Queiroz LH. Avaliação do método de aspiração na colheita de cérebro de morcegos para diagnóstico da raiva. Arq Inst Biol Sao Paulo. 2009;76:701-5.

15. Gregorin R, Taddei VA. Chave artificial para a identificação de molossídeos brasileiros (Mammalia, Chiropteros). Mastozool Neotrop. 2002;9:13-32.

16. Handley CO Jr. New species of mammals from Northern South America: fruit-eating bats, genus Artibeus Leach, 1821. In: Patterson BD, Timm RM, editors. Studies in Neotropical mammalogy : essays in honor of Philip Hershkovitz. Fieldiana: Zoology; 1987. (New Series no. 39).

17. Hayman DTS, Bowen RA, Cryan PM, McCracken GF, O‘Shea TJ, Peel AJ, et al. Ecology of zoonotic infectious diseases in bats: current knowledge and future directions. Zoonoses Public Health. 2013;14:2-21.

18. International Committee on the Taxonomy of Virus (ICTV). Virus taxonomy: classification and nomenclature of virus. In: Fauguet CM, Mayo MA, Manilo FFJ, Desseberger U, Ball LA, editors. $8^{\text {th }}$ Report of the International Committee on the Taxonomy of Virus. San Diego: Elsevier/Academic Press; 2005. p. 981-98.

19. Instituto Brasileiro de Geografia e Estatística. Informações sobre os municípios brasileiros : Capanema-PA; 2010. Brasília : IBGE; 2010. Available from: http://www. cidades.ibge.gov.br

20. Kunz TH, Robson SK. Postnatal growth and development in the Mexican free-tailed bat (Tadarida brasiliensis mexicana): birth size, growth rates, and age estimation. J Mammal. 1995;76:769-83.

21. Lee YF, McCracken GF. Timing and variation in the emergence and return of Mexican free-tailed bats, Tadarida brasiliensis mexicana. Zool Stud. 2001;40:309-16.

22. Linares OJ. Murcielagos de Venezuela. Cuadernos Lagoven. Caracas: Departamento de Relaciones Públicas de Lagoven; 1987.

23. Mattos CA, Favi M, Yung V, Pavletic C, Mattos CC. Bat rabies in urban centers in Chile. J Wildl Dis. 2000;36:231-40.

24. Meslin FX, Kaplan MM, Koprowisk H. Laboratory techniques in rabies. $4^{\text {th }}$ ed. Geneva: World Health Organization; 1996. 


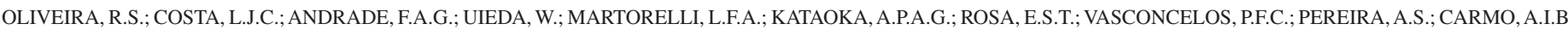
\& FERNANDES, M.E.B. - Virological and serological diagnosis of rabies in bats from an urban area in the Brazilian Amazon. Rev. Inst. Med. Trop. Sao Paulo, 57(6): 497-503, 2015.

25. Organización Panamericana de la Salud (OPS). Vigilancia epidemiológica de la rabia en las Americas; 2004. Available from: http://bvs.panaftosa.org.br/textoc/bolvera2004. pdf

26. Picard-Meyer E, Dubourg-Savage MJ, Arthur L, Barataud M, Bécu D, Bracco S, et al. Active surveillance of bat rabies in France: a 5-year study (2004-2009). Vet Microbiol. 2011;151:390-5

27. Plowright RK, Field HE, Smith C, Divljan A, Palmer C, Tabor G, et al. Reproductive and nutritional stress are risk factors for Hendra virus infection in little red flying foxes (Pteropus scapulatus). Proc R Soc B. 2008;275:861-9.

28. Price JL, Everard COR. Rabies vírus and antibody in bats in Grenada and Trinidad. J Wildl Dis. 1977;13:131-4.

29. Reis NR, Peracchi AL, Pedro WA, Lima IP. Mamíferos do Brasil, 2a ed. Londrina; N.R. Reis; 2011.

30. Rocha EJP, Souza EB, Santos FAA, Lopes MN, Santos DM, Rolim PAM, et al. Zoneamento ecológico econômico do Pará. Sistema de Proteção da Amazônia SIPAM. Belém: Centro Regional de Belém; 2009. p. 27.

31. Rosa ES, Kotait I, Barbosa TFS, Carrieri ML, Brandão PE, Pinheiro AS, et al Bat-transmitted human rabies outbreaks, Brazilian Amazon. Emerg Infect Dis. 2006;12:1197-202

32. Rupprecht CE. Evolution of public health recommendations for human rabies prophylaxis after bat exposure in the United States. In: Basgoz N, editor. Rethinking rabies risks sharpening clinical skills for a reemergence threat. Boston: Harvard Medical School; 2000.

33. Rupprecht CE, Hanlon CA, Hemachudha T. Rabies re-examined. Lancet Infect Dis. 2002;2:327-43.
34. Salas-Rojas M, Sánchez-Hernández C, Romero-Almaraz ML, Schenll GD, Schmid RK, Aguilar-Setién A. Prevalence of rabies and LPM paramyxovirus antibody in non-hematophagous bats captured in the Central Pacific coast of Mexico. Trans R Soc Trop Med Hyg. 2004:98:577-84.

35. Salmón-Mulanovich G, Vásquez A, Albújar C, Guevara C, Laguna-Torres VA, Salazar $\mathrm{M}$, et al. Human rabies and rabies in vampire and nonvampire bat species, Southeastern Peru. Emerg Infect Dis. 2009;15:1308-10.

36. Schneider MC, Belotto A, Adé MP, Leanes LF, Correa E, Tamayo H. et al. Epidemiologic situation of human rabies in Latin American in 2004. Epidemiol Bull. $2005 ; 26: 2-4$

37. Schneider MC, Romijn PC, Uieda W, Tamayo H, Silva DF, Belotto A, et al. Rabies transmitted by vampire bats to humans: an emerging zoonotic disease in Latin America? Rev Panam Salud Publica. 2009;25:260-9.

38. Smith JS, Yager PA, Baer GM. A rapid fluorescent focus inhibition test (RFFIT) for determining rabies virus neutralizing antibodies. In: Meslin FX, Kaplan MM Koprowski H, editors. Laboratory techniques in rabies. $4^{\text {th }}$ ed. Genebra: World Health Organization; 1996. p. 181-92.

39. Sodré MM, Gama AR, Almeida MF. Updated list of bat species positive for rabies in Brazil. Rev Inst Med Trop Sao Paulo. 2010;52:75-81.

40. Steece RS, Calisher CH. Evidence for prenatal transfer of rabies virus in the Mexican free-tailed bat (Tadarida brasiliensis mexicana). J Wildl Dis. 1989;25:329-34.

41. Turmelle AS, Allen LC, Jackson FR, Kunz TH, Rupprecht CE, McCracken GF Ecology of rabies virus exposure in colonies of Brazilian free-tailed bats (Tadarida brasiliensis) at natural and man-made roosts in Texas. Vector Borne Zoonotic Dis. 2010;10:165-75

Received: 18 October 2014

Accepted: 31 March 2015 


\section{LIBRARY OF THE \\ SÃO PAULO INSTITUTE OF TROPICAL MEDICINE}

Website: http://www.imt.usp.br/sobre-o-imtsp/biblioteca

Address: Biblioteca do Instituto de Medicina Tropical de São Paulo da Universidade de São Paulo Av. Dr. Enéas de Carvalho Aguiar, 470.

05403-000 - São Paulo - SP - Brazil.

Telephone: 5511 3061-7003
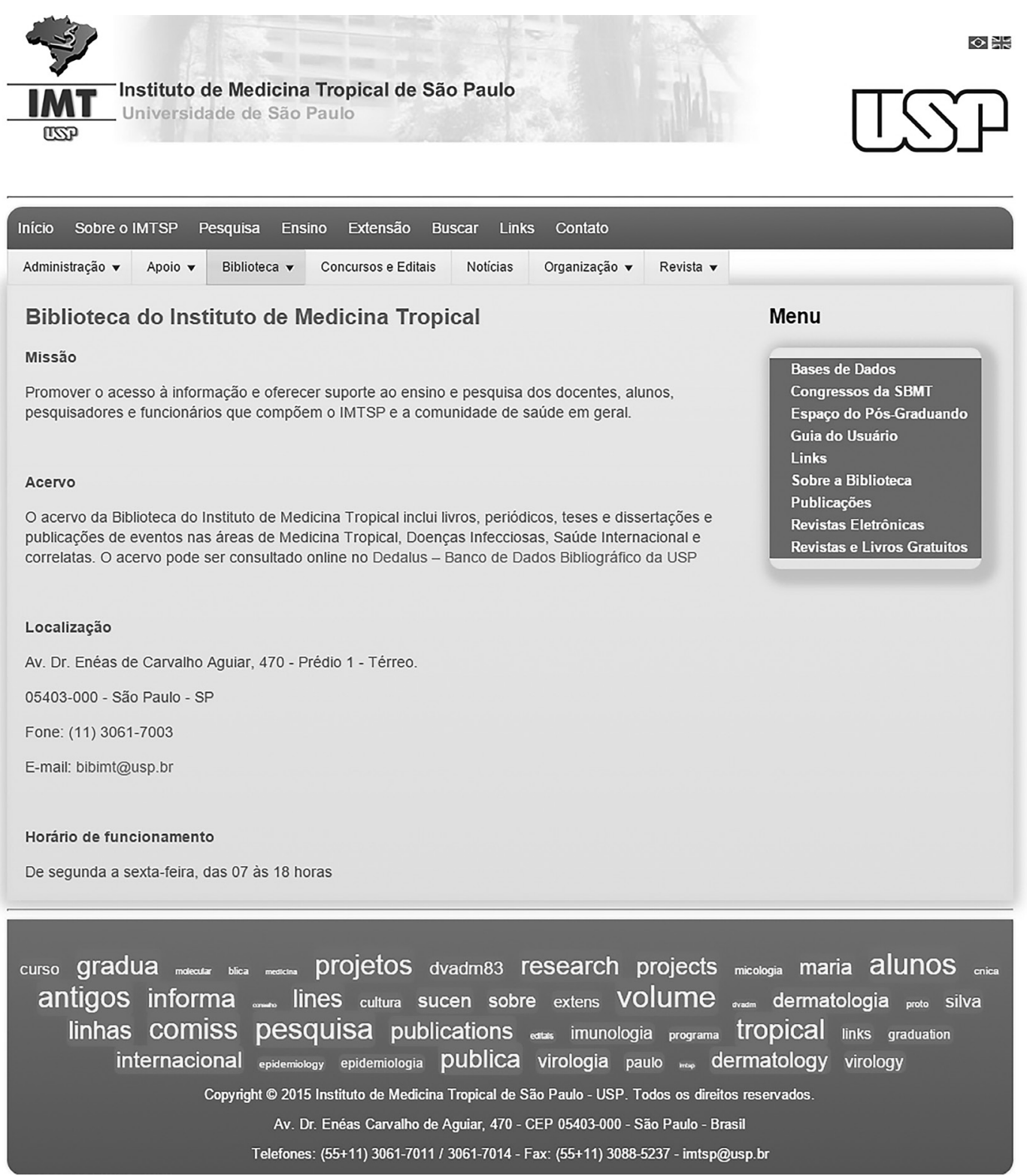

The Library of the São Paulo Institute of Tropical Medicine (IMTSP Library) was created on January 15, 1959 in order to serve all those who are interested in tropical diseases.

The IMTSP Library has a collection consisting of books, theses, annals of congresses, journals, and reference works.

The collection of the Library can be searched through the USP Bibliographic Database - Dedalus at the URL http://200.144.190.234/F 